\title{
Return of grey wolf (Canis Iupus) to Central Europe: challenges and recommendations for future management in cultural landscapes
}

\author{
Sven Herzog
}

Herzog S., 2018. Return of grey wolf (Canis lupus) to Central Europe: challenges and recommendations for future management in cultural landscapes. Ann. For. Res. 61(2): 203-209.

Abstract. Grey wolf actually is immigrating Central Europe from eastern or southern populations, establishing packs and reproducing successfully. This development, starting in the beginning of the 2000 s, led to an exponential population increase until today. The present paper analyzes re-colonization of Central Europe by Grey wolf (Canis lupus), considering ecological, socio-economical as well as socio-cultural aspects, and develops basic points for an exemplary management concept. Until today, wolf management especially in Germany, Austria and Switzerland, widely follows a passive "wait and see" strategy. Thus, predations of small livestock, cattle, and horses are quickly increasing. Especially farmers and herdsmen call for a more active way of wolf management. The Central European populations of mouflon (Ovis ammon musimon), being highly endangered in its natural range, are completely disappearing with the occurrence of wolf. Hunting of wild ungulates becomes more difficult whereas forest damages by barking and browsing are not significantly reduced by the influence of wolf predation. Maintaining biodiversity by preserving open landscapes by grazing might become more and more difficult. The present paper shows the need for a more active management concept, developed from a participatory process, locally differentiated and combining different management measures, as e.g. total protection, sustainable utilization, prevention of diseases, herd protection measures and others.

Keywords: Grey wolf, Canis lupus, Central Europe, re-colonization, conflicts, protection, management

Author. Dresden University of Technology, Chair of Wildlife Ecology and Management, Pienner Strase 8 D-01737 Tharandt, Germany. Email: herzog@ forst.tu-dresden.de

Manuscript received November 4, 2018; revised December 26, 2018; accepted December 29, 2018; online first December 31, 2018. 


\section{Introduction}

Grey wolf actually is re-colonizing Central Europe by immigration from eastern or southern populations, establishing packs and successful reproduction. This development, starting in the beginning of the 2000s, led to an exponential population increase until today (Herzog 2014). Recent management strategies are mainly restricted to the observation and monitoring of re-colonization, supplemented by some regulations concerning compensation payments. The situation in Switzerland and Austria is similar. Conflicts between man and wolf are quickly increasing. Thus, actual wolf management plans and respective legislation have to be revised and improved on a scientific basis. For the future, the existing management approach has to be amended by defining clear goals and taking different measures of management into consideration, including the whole spectrum from scaring off wolves from herds and settlements to regular, sustainable utilization.

From a wildlife management as well as nature conservation point of view, the goal of wolf management should be to establish viable, adaptable populations in suitable habitats, which is accepted by the local land users and by the local human population (Herzog, 2016). Grey wolf has a wide ecological spectrum: presence of food and absence of illegal or non-sustainable hunting or are the preconditions required.

There are only few scientific data on the Central European situation that may serve as a basis for management recommendations. The present paper reviews the most relevant informations to build a scientific basis for future management concepts. The main challenges and recommendations for a wolf management on a scientific basis in Central Europe will be compiled.

\section{Status of the species}

The status of a species, according to the European Council Directive on the Conservation of Natural Habitats and of Wild Fauna and Flora, has to be classified as "favourable" when population dynamics data indicate that it will exist on a long term basis as a viable component of its natural habitat. Additionally, the natural range of the species should neither being reduced nor it is likely to be reduced for the future. A third requirement is concerning habitats: they have to be able to maintain the population on a long-term basis. Today, according to these conditions, Grey wolf in Central Europe is in a favourable state of preservation (Herzog \& Guber 2018). However, in the European Union, the management of large predators ranges from a sustainable utilization by regular, controlled hunting (as e.g. in Estonia) to total protection (as e.g. in Germany or Austria, see also Guber \& Herzog 2017).

\section{Anthropogenic mortality and population dynamics}

The question if anthropogenic mortality in large mammal species is tending to be either additive or compensatory is not new (see e.g. Ellenberg 1978, Lebreton 2005). Today we recognize that this question has to be differentiated concerning species as well as concerning the actual status of a (sub)population. Compensatory mechanisms might be especially a higher reproduction rate, and/or a reduction of other anthropogenic and/or natural factors influencing mortality.

Previous studies on Grey wolf (see e.g. Jędrzejewska et al., 1996; Mörner et al. 2005, Lovari et al. 2007, Brainerd et al. 2008, Creel and Rotellea 2010, Liberg et al. 2011, Sparkman et al. 2011) are dealing with this question, looking at the phenomenon of "anthropogenic mortality" in toto. As Herzog (2014) stressed, consequences of a controlled, sustainable utilization are different from those of "predator 
control" measures or even poaching. In addition, there is no doubt that the effects of anthropogenic influences are different for (sub) populations of only one or few wolf packs, compared to a well-established, constantly growing subpopulation.

We can subdivide anthropogenic mortality into at least four different categories (see Table 1). The German subpopulation, regarded as the westernmost part of the huge Baltic-Eastern European wolf population, actually shows an unbowed exponential growth. Road kills are assumed to be the most important mortality factor and even this factor is shown to be of compensatory character (Herzog 2014).

Regardless of the presumably low impact of wolf road-kills on population dynamics of the species, management in the special situation of a densely inhabited landscape with huge urban region and a close-meshed network of roads and railroad tracks calls for particular solutions to avoid vehicle-wolf collisions (see also Polster et al. 2014, Polster \& Herzog 2014).

\section{Predation of wildlife}

In Central Europe we know the wolf prefers Roe deer (Capreolus capreolus) and Red deer (Cervus elaphus) as prey species, followed by Wild boar (Sus scrofa); for details, see Wagner et al. (2012). We have actually no reliable scientific data, but it seems that local subpopulations of these species are only slightly influenced by lowering their abundance, but a serious threat could not be observed. Reports of significant reductions of population size and, finally, local extinction, concern espe- cially mouflon (Ovis ammon musimon). This leads to an intrinsic conflict of different species conservation goals. This sheep subspecies is highly endangered in its natural habitats in Corsica and Sardinia. The Central European populations represent the majority of the gene pool of he subspecies and might be regarded as a very effective ex-situ gene conservation measure (see e.g. Piegert \& Uloth 2000, Herzog \& Schröpfer 2016).

\section{Predation of livestock}

Predation of livestock is actually the most critical area of conflicts in Central Europe. Actually, the focal point is the predation of small livestock such as sheep, goats, alpacas or farmed fallow deer. Actually, financial support of measures of herd protection, primarily by fencing, and compensation payments are the tools favored by administration and politics. However, it is still unclear how a long period of total protection of wolves will lead to a significant loss of timidity. This would result in a decreasing efficiacy of protective measures and, as a consequence, an increased rate of livestock predation.

Another problem, especially in Germany or Austria, is the fact that Red deer (Cervus elaphus) as an important prey species is extinct in major parts of its natural range. Due to forest economic and agricultural concerns, red deer is not tolerated in huge parts of the potential wolf areas. We know from Belarus (Sidorovich et al. 2003) and the Iberian Peninsula (Vos 2000, Torres et al. 2015) that the proportion of livestock predation is critically dependent on the

Table 1 Categories of anthropogenic mortality in large predators (following Herzog 2014)

\begin{tabular}{ll}
\hline Category & Examples \\
\hline Predator control & $\begin{array}{l}\text { Intentional, more or less controlled reduction of population size. } \\
\text { Actually not practiced in Central Europe. }\end{array}$ \\
\hline Sustainable hunting & Controlled, planned wolf hunting for utilization e.g. in Baltic states. \\
\hline $\begin{array}{l}\text { Illegal hunting, not sustainable } \\
\text { hunting, poaching }\end{array}$ & Killings from different reasons without (legal) control \\
\hline Accidents (unintentional) & Collisions along roads or railroad tracks, strangulation in fences \\
\hline
\end{tabular}


presence respectively abundance of wild ungulates.

Actually, predation an increasing number of larger livestock such as cattle or horses shows up (Anonymus 2016, 2017). Apart from economical as well as non-material value of these animals, the killing in enclosures or wounding of high numbers of individuals implies even an animal welfare problem.

For the future, we have to be aware that the risk of traffic collisions with animals brought into panic by wolf attacks will increase. This bears the risk of immense economic impact and body-injuries indirectly resulting from wolf attacks (not necessarily predation) on livestock (Herzog 2016).

Also from a nature conservation viewpoint, there are serious conflicts. Grazing with livestock is an important and relatively cost efficient method of keeping landscapes open and prohibit special protected plant societies from succession. If livestock farming is becoming uneconomical by presence of the wolf, these conservation concepts in open landscape protection will fail at a long-term scale.

\section{Hybridization}

The question of hybridization between wolf and domestic dog, as well as between wolf and jackal (Canis aureus) in Central Europe is still unanswered. Dependent on the role of hybridization in the past, especially in the abruzzo-alpine wolf population, beeing over centuries in more or less narrow contact to domestic dogs, we have actually no clear evidence if molecular markers are discriminative or not (see e.g. Tsuda et al. 1997, Randi et al. 2014). As recent studies show, admixtures of canid taxa, previously regarded as different species, are regularly occurring (von Holdt et al. 2016).

The central problem of hybrids between domestic dog and wolf is the problem of maintainance of timidity (Herzog 2016). Decades of dog breeding contributed to a reduced timidity against man. Hybridization is assumed to increase the risk of wolf attacks against man and thus it bears an immense risk of increasing conflicts.

In this context, we have also to ask, if the renouncement of re-introduction of single wolf individuals will be helpful to avoid hybridization. Maybe, active release of a male or female might help to reduce the risk of hybridization, if a single wolf is to be observed in a region over a longer period (Herzog 2016).

\section{Diseases}

Out of the number of diseases wolf can suffer from, only a few are relevant for active wolf management (see also Brand et al. 1995, Mörner et al. 2005). Maybe not most important, but for avoidance of conflicts most relevant is rabies. We know that wolf was a major factor for transmission of this zoonosis to man in the past. The extinction of wolf in the $18^{\text {th }}$ and $19^{\text {th }}$ century made red fox (Vulpes vulpes) increasingly important in that context. Actually, responsible authorities have no concept of prevention, especially no vaccination concept, neither for the wolf, nor (especially in Saxony with the highest wolf abundances in Western Europe) for the fox.

In addition, distemper, aujeszky's disease and (with increasing abundances of wolf) scabies will maybe also play a major role in the future. However, these diseases will be not so controversial, but maybe they will be able to reduce abundance significantly.

\section{Conclusions: from passive "wait and

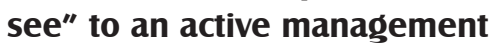

Actually, most of the Central European countries are tending to a total protection concept, with no active influence on the population. Wolf management in Germany and Austria is a kind of passive observation of the ongoing situation. Increasing conflicts show that this strategy might be a proper approach in an early state of a re-colonization process, but that is bound to fail after a successful (even local) recolonization. 
To avoid major risks for the future, the existing concepts have to be replaced by a more sophisticated approach, defining clear goals and taking different measures of management into consideration.

A view at the situation in France, Slovakia Scandinavia or the Baltic countries shows us that a more differentiated, active wolf management could help to overcome the above mentioned problems.

A local differentiation and a combination of different management measures - e.g. total protection, local killings of problematical individuals, sustainable utilization, prevention of diseases, herd protection measures and a management concept developed from a participatory process should be a solution.

This would mean that we have to differentiate regionally, e.g. as follows: (a) regions with immigrating single individuals, but no reproduction and no territorial packs, (b) regions where first sessile territorial wolf packs occur, reproducing and slowly building up a local subpopulation and (c) regions being area-wide colonized with sessile, territorial wolf packs, reproducing over several years.

Whereas in the situation of (a) a total protection concept with additional herd protection activities seems to be adequate, the situations (b) and (c) call for a modified approach. Case (b) means increasing predation of domestic livestock and thus increasing conflicts. In this case, we need an implementation of a participatory process. Following Riley et al. (2003), two questions to be asked at that stage are "(1) what is the range of impacts occurring now and expected in the future and (2) who are the key stakeholders". Actually, small livestock farmers and herdsmen are to be identified to be the key stakeholders. This would mean that the increasing predation of livestock with the above mentioned economical, ecological as well as animal welfare problems. Thus, beside passive herd protection measures as fencing, we should develop active management tools. Whereas e.g. Germany or Austria actually only allow the removal of single "problematical" 207 individuals by specially authorized conservation officials, other countries such as Sweden (Frank 2016) or France (Anonymous 2018) are not focused on single individuals. They developed local hunting concepts to protect livestock by reduction of local wolf abundances, reinforced by the antagonizing or repelling effects of hunting itself. Local hunters or even herdsmen are integrated into these concepts. Case (c), actually reached in the eastern and some central parts of Germany, calls for a concept of regular, sustainable hunting, such as established in the Baltic countries.

Concerning the impact of killing single individuals from a pack, there are no experiences from Europe. We have some reports from the Western U.S.A., where Musiani et al. (2005), Harper et al. (2008) or Wieglus \& Peebles (2014) found only slightly reduced or even increased predation rate after killing single wolf individuals. However, these studies refer to few, partly uncontrolled interventions. On the other hand, Bradley et al. (2015) showed that predation activity is a function of the size of the remaining wolf pack after an intervention. Thus, hunting or reduction concepts should be improved by focusing primarily on juvenile individuals. This would reduce the risk of killing alpha-Individuals and thus de-stabilizing the pack.

Although rabies currently doesn't play a significant role in Central Europe, and in Eastern Europe Red fox (Vulpes vulpes) represents the main reservoir, the Grey wolf is also involved in virus circulation, dependent on the population density (Kuzmin et al. 2004). Thus, there is a risk of new outbreaks resulting from immigrating individuals from Eastern Europe. As a consequence, vaccination against rabies should be recommended for the wolf in central Europe.

We presented here in short that an active management of re-migrating wolves is needed especially in Central Europe, with the particular civilisatory situation. Failure of wolf management would mean huge problems for the wolf, as well as for man in the future. Thus, we 
should focus on a foresight strategy, including a sophisticated concept of management measures, covering the whole spectrum of management methods in the near future to prevent conflicts are getting out of hand.

\section{References}

Anonymous, 2016. Wolfsverursachte Schäden, Präventions- und Ausgleichszahlungen in Deutschland (2015) [Injuries caused by wolves, payments for prevention and compensations in Germany (2015)]. Dokumentations- und Beratungsstelle des Bundes zum Thema Wolf, 22 pages. Web: https://www.dbb-wolf.de/mehr/ literatur-download/berichte-zu-praevention-und-nutztierschaeden Accessed: 10.2018.

Anonymous, 2017. Wolfsverursachte Schäden, Präventions- und Ausgleichszahlungen in Deutschland (2016) [Injuries caused by wolves, payments for prevention and compensations in Germany (2016)]. Dokumentations- und Beratungsstelle des Bundes zum Thema Wolf, 29 pages. Web: https://www.dbb-wolf.de/mehr/ literatur-download/berichte-zu-praevention-und-nutztierschaeden Accessed: 10.2018.

Anonymous, 2018. Plan national d'actions 2018-2023 sur le loup et les activités d'élevage [National action plan on wolf and the contrl activities]. Web: http://agriculture.gouv.fr/plan-national-dactions-2018-2023-sur-leloup-et-les-activites-delevage-0 Accessed: 10.2018.

Bradley E.H., Robinson H.S., Bangs E.E., Kunkel K., Jimenez M.D., Gude J.A., Grimm T., 2015. Effects of wolf removal on livestock depredation recurrence and wolf recovery in Montana, Idaho, and Wyoming. Journal of Wildlife Management 79: 1337-1346. DOI: 10.2193/2006-305

Brainerd S.M., Bangs E.E., Bradley E.H., Fontaine J.A., Hall W., Iliopoulos Y., Jimenez M.D., Jozwiak E.A., Liberg O., Mack C.M., Meier T.J., Niemeyer C.C., Pedersen H.C., Sand H., Schultz R. N., Smith D.W., Wabakken P., Wydeven A.P., 2008. The effects of breeder loss on wolves. Journal of Wildlife Management 72 : 89-98. DOI: 10.2193/2006-305

Brand C. J., Pybus M. J., Ballard W.B., Peterson R.O., 1995. Infectious and parasitic diseases of the grey wolf and their potential effects on wolf populations in North America. In: Carbyn L.N. (ed.), Ecology and conservation of wolves in a changing world. Canadian Circumpolar Institute, Edmonton, pp. 419-429.

Creel S., Rotellea J.J., 2010. Meta-analysis of relationships between human offtake, total mortality and population dynamics of gray wolves (Canis lupus). PloS One 5: 1-7. DOI: 10.1371/journal.pone.0012918

Ellenberg H., 1978. Zur Populationsökologie des Rehes (Capreolus capreolus L., Cervidae) in Mitteleuropa [On population ecology of roe deer (Capreolus capreo- lus L., Cervidae) in Central Europe.]. Spixiana, ZoologischeStaatssammlung, Suppl. 2, 211 .

Frank J., 2016. Nära vargar. Rekommendationer för hantering av situationer med vargarnära bos-tadshus eller männlskor [Near wolves. Recommendations for handling situations with wolves near inhabited areas]. Viltskadecenter (lnstitutionen för ekologi, Sveriges Lantbruksuniversitet), $32 \mathrm{p}$.

Guber S., Herzog S., 2017. Die naturschutzrechtliche raum- und wirkungsbezogene Klassifikationssystematik von Arten sowie daraus folgende staatliche Handlungspflichten - erläutert an den Arten Mufflon (Ovis ammon musimon) und Wolf (Canis lupus) [Classification systematics of species with respect to nature conservation legislation, and resulting public commitments, using the species mouflon (Ovis ammon musimon) und grey wolf (Canis lupus) as examples]. Natur und Recht 39: 73-88. DOI 10.1007/s10357-017-3133-0

Harper E.K., Paul W.J., Mech L.D., Weisberg S., 2008. Efectiveness of lethal, directed wolf depredation control in Minnesota. Journal of Wildlife Management 72: 778-784. DOI: $10.2193 / 2007-273$

Herzog S., 2014. Mortalität durch Verkehrswege beim Wolf (Canis lupus) - ein Artenschutzproblem? [Wolf (Canis lupus) mortality caused by traffic routes - a species conservation problem?] Säugetierkundliche Informationen 9: 235-242.

Herzog S., 2016. Von Wölfen und Menschen: Für einen undogmatischen Umgang mit einem Heimkehrer [About wolves and men: for an undogmatic concern with a returning species]. Beiträge zur Jagd- und Wildforschung 41: 227-237.

Herzog S., Guber S., 2018. Der naturschutzrechtliche Populationsbegriff als Maßstab zur Beurteilung des Erhaltungszustandes einer Art gem. $§ 45$ Abs. 7 S. 2 BNatschG erläutert am Beispiel des Wolfes (Canis lupus) [The population concept in nature conservation legislation as a standard for the conservation status of a species according to $\S 45$ (7) S. 2 German Federal Nature Conservation Law, discussed using grey wolf (Canis lupus) as an example]. Natur und Recht 40: 682688. DOI 10.1007/s10357-018-3416-0

Herzog S., Schröpfer R., 2016. Das Mufflon Ovis ammon musimon (Pallas, 1811) in Europa: Faunenverfälschung oder Maßnahme der ex-situ-Generhaltung? [The mouflon in Europe: forgery of fauna or measure of ex-situ gene conservation?] Säugetierkundliche Informationen 10(52): 259-264.

Jędrzejewska B., Jędrzejewski W., Bunevich A.N., Minkowski L., Okarma H., 1996. Population dynamics of wolves Canis lupus in Biolowieża Primeval Forest (Poland and Belarus) in relation to hunting by humans, 1847-1993. Mammal Review 26: 103-126. DOI: 10.1111/j.1365-2907.1996.tb00149.x

Kuzmin I.V., Botvinkin A.D., McElhinney L.M., Smith J.S., Orciari L.A., Hughes G.J., Fooks A.R., Rupprecht C.E., 2004. Molecular epidemiology of terrestrial rabies in the former Soviet Union. Journal of Wildlife Diseas- 
es 40: 617-631. DOI: 10.7589/0090-3558-40.4.617

Lebreton J.-D., 2005. Dynamical and statistical models for exploited populations. Australian \& New Zealand Journal of Statistics 47(1): 49-63. DOI: 10.1111/j.1467842X.2005.00371.x

Liberg O., Chapron G., Wabakken P., Pedersen H.C., Hobbs N.T., Sand H., 2011. Shoot, shovel and shut up: cryptic poaching slows restoration of a large carnivore in Europe. Proceedings of the Royal Society B: Biological Sciences 279: 910-915. DOI: 10.1098/ rspb.2011.1275.

Lovari S., Sforzi A., Scala C., Fico R. 2007. Mortality parameters of the wolf in Italy: does the wolf keep himself from the door? Journal of Zoology 272, 117-124. DOI:10.1111/j.1469-7998.2006.00260.x.

Mörner T., Eriksson H., Bröjer C., Nilsson K., Uhlhorn H., Ågren E., Hårdaf Segerstad C., Jansson D.S., Gavier-Widén D., 2005. Diseases and mortality in free-ranging brown bear (Ursus arctos), gray wolf (Canis lupus), and wolverine (Gulo gulo) in Sweden. Journal of Wildlife Diseases 41(2): 298-303. DOI: 10.7589/00903558-41.2.298

Musiani M., Muhly T., Gates C., Callaghan C., Smith M.E., Thsoni E., 2005. Seasonality and reoccurrence of depredation and wolf control in western North America. Wildlife Society Bulletin 33: 876-887. DOI: 10.2193/0091-7648(2005)33[876:SARODA]2.0.CO;2

Piegert H., Uloth W., 2000. Der Europäische Mufflon [The European mouflon]. DSV-Verlag, Hamburg.

Polster J.-U., Pfarre C., Herzog S., 2014. Möglichkeiten der olfaktorischen und akustischen Vergrämung des Wolfes (Canis lupus) an Verlehrswegen: Erste Ergebnisse einer Gehegestudie [Olfactoric or accustic measures to repel wolves (Canis lupus) from traffic routes. first results of a study in an enclosure]. Säugetierkundliche Informationen 9(48): 281-288.

Polster J.-U., Herzog S., 2014. Studies on deterrent agents for predator and prey species to avoid wildlife collisions along transport routes on the example of Grey wolf (Canis lupus) and Red deer (Cervus elaphus). Mammalian Biology 79S, 16.

Randi E., Hulva P., Fabbri E., Galaverni M., Galov A., Kusak J., Bigi D., Bolfíková B.Č., Smetanová M., Caniglia R. 2014. Multilocus detection of wolf $x$ dog hybridization in Italy, and guidelines for marker selection. PLoS One 9(1): e86409. DOI: 10.1371/journal.pone.0086409
Riley S.J., Siemer W.F., Decker D.J., Carpenter L.H., Organ J.F., Berchielli L.T., 2003. Adaptive impact management: An integrative approach to wildlife management. Human Dimensions of Wildlife 8: 81-95. DOI: 10.1080/10871200304301

Sidorovich V.E., Tikhomirova L.L., Jedrzejewska B., 2003. Wolf Canis lupus numbers, diet and damage of livestock in relation to hunting and ungulate abundance in northeastern Belarus during 1990-2000. Wildlife Biology 9: 103-111. DOI: 10.2981/wlb.2003.032

Sparkman A.M., Waits L.P., Murray D.L., 2011. Social and demographic effects of anthropogenic mortality: A test of the compensatory mortality: hypothesis in the Red wolf. PLoS One 6(6): e20868. DOI:10.1371/journal.pone. 0020868 .

Torres R.T., Silva N., Brotas G., Fonseca C., 2015. To eat or not to eat? The diet of the endangered Iberian Wolf (Canis lupus signatus) in a human-dominated landscape in Central Portugal. PloS One 10(6): e0129379. DOI: 10.1371/journal.pone.0129379.

Tsuda K., Kikkawa Y., Yonekawa H., Tanabe Y., 1997. Extensive interbreeding occured among multiple matriarchal ancestors during the domestication of dogs: Evidence from inter- and intraspecies polymorphisms in the D-loop region of mitochondrial DNA between dogs and wolves. Genes \& Genetic Systems 72(4): 229-38. DOI: $10.1266 /$ ggs. 72.229

Von Holdt B.M., Cahill J.A., Fan Z., Gronau I., Robinson J., Pollinger J.P., Shapiro B., Wall J., Wayne R.K. 2016. Whole-genome sequence analysis shows that two endemic species of North American wolf are admixtures of the coyote and gray wolf. Science Advances 2(7): e1501714. DOI: 10.1126/sciadv. 1501714

Vos J., 2000. Food habits and livestock depredation oft two Iberian wolf packs (Canis lupus signatus) in the north of Portugal. Journal of Zoology 251: 457-462. DOI: $10.1111 /$ j.1469-7998.2000.tb00801.x

Wagner C., Holzapfel M., Kluth G., Reinhardt I., Ansorge H., 2012. Wolf (Canis lupus) feeding habits during the first eight years of its occurence in Germany. Mammalian Biology 77: 196-203. DOI: 10.1016/j.mambio.2011.12.004

Wieglus R.B., Peebles K.A., 2014. Effects of wolf mortality on livestock depredations. PloS ONE 9(12):e113505. DOI: 10.1371/journal.pone.0113505 
